\title{
OS GÊNEROS DO DISCURSO NA CLÍNICA FONOAUDIOLÓGICA: um estudo de caso
}

\author{
SPEECH GENRES IN THE LANGUAGE THERAPY: \\ a study case
}

\author{
Rita de Cássia Fernandes Signor ${ }^{1}$ \\ Mestranda em Lingüística - UFSC
}

\begin{abstract}
Resumo
A problemática em torno da aprendizagem da leitura e escrita, sob nosso ponto de vista, reflete um fenômeno social. A escola, pautada em uma concepção autônoma de letramento, termina por inserir seus sujeitos em práticas de leitura e escrita pouco significativas e, em vista disso, os distúrbios de linguagem são constituídos. Assim, ao tomarmos a teoria de gêneros do discurso como objeto terapêutico, preconizamos que, através das relações de sentido que tal teoria supõe, possamos reverter o quadro de instabilidades decorrentes de relações sofríveis com a escrita. O objetivo deste trabalho é apresentar um estudo de caso de terapia fonoaudiológica centrada na teoria bakhtiniana de gêneros. A pesquisa deteve-se na aplicação de uma proposta didática, relacionada ao gênero crônica, a um grupo de três adolescentes em curso terapêutico (encaminhados pela escola por apresentarem “distúrbios” de escrita). Foram necessárias dez sessões de atendimento para que o processo fosse finalizado ${ }^{2}$. Desse modo, seguindo o método proposto por Bussarello ${ }^{3}$ (2004), utilizamos três sessões para as leituras-entretenimento das crônicas selecionadas; mais quatro sessões para a etapa das leituras analíticas do gênero; e, por fim, outras três sessões para a produção das crônicas pelos pacientes, incluindo os processos de revisão e reescritura. Os resultados levam a crer que os adolescentes conseguiram produzir textos adequados ao gênero em questão. As estratégias para causar o impacto no leitor é que balizaram todo o procedimento de produção textual, sendo as questões formais e textuais requeridas como um suporte para a concretização da intenção discursiva dos sujeitos.
\end{abstract}

Palavras-chave: “Distúrbios” de escrita. Terapia fonoaudiológica. Gênero crônica. Produção Textual.

\begin{abstract}
The problematic concerning the reading and writing learning process, under our point of view, is a social matter. Schools, aiming at an independent literacy conception, ends up by inserting its subjects in reading and writing practices little significant; nevertheless, the language disorders are constituted. Thus, when taking the theory of genres of the speech as therapeutical object, through the meaning of relations that such theory proposes, we might be able to revert the scenario of instabilities decurrent from suffered relations with the writing abilities. The aim of this paper is to present a case of speech

\footnotetext{
${ }^{1}$ Fonoaudióloga. Especialista em Motricidade Orofacial.

${ }^{2}$ Referimo-nos ao gênero específico crônica. Obviamente, o processo terapêutico como um todo engloba o trabalho com outros gêneros.

${ }^{3}$ Na realidade, fizemos uma transposição de método, com adaptação para o contexto terapêutico.
} 
therapy study centered at the Bakhtin genres theory. The research was lingered in the application of a didactic proposal related to the chronic genre, to a group of three adolescents in a therapeutical course process (directed by the school for presenting "riots" of writing). Ten sessions of attendance had been necessary so that the process was finished. In this manner, referring the proposed method by Bussarello (2004), we used three sessions for the reading- entertainment of the selected chronicles; four more sessions for the analytical reading stage; and, at last, three other sessions for the patient's chronicles, including the revision and the rewriting processes. The results lead to believe that the adolescents were able to produce adequate texts to the genre in question. The strategies to cause the impact in the reader are the ones that marked out all the literal production proceedings, and the formal and literal questions are required as a support for the concretion of the discursive intention of the subjects.

Keywords: Language disorders. Speech therapy. Chronic genre. Literal production.

\section{INTRODUÇÃO}

A questão da leitura e da escrita em nosso país está sendo muito mais vinculada à noção de fracasso do que de sucesso. Essa situação, sentida sobretudo por crianças com entorno desfavorável de letramento, vem sendo tomada como prevista e justificada por professores e terapeutas como uma problemática constitutiva dos sujeitos. A escola pública, inserida nos padrões de classe média, supõe um desenvolvimento lingüístico que as crianças oriundas de meios sociais desprivilegiados muitas vezes não têm. Em vista disso, o aluno que não atinge o padrão esperado pela escola passa a ser concebido como “deficitário". Discute-se a problemática em termos de considerações acerca do que "faltou" para que o sujeito suprisse as metas impostas; mas não se pensa no que faltou à escola para que cumprisse a sua função de ensinar. $\mathrm{O}$ fonoaudiólogo, ao aceitar a queixa da escola, deve estar bem fundamentado para que não incorra em equívocos ao diagnosticar ${ }^{4}$, sob o risco de afastar ainda mais o sujeito da linguagem escrita em processo de apropriação.

Partimos do ponto de vista de que os problemas decorrentes do insucesso na aprendizagem da leitura e da escrita refletem uma problemática social. A escola, orientada por um modelo autônomo de letramento, desconsidera a realidade de seus sujeitos, mostra-se inflexível ao apresentar um ensino em contextos nada significativos. Apagam-se os usos em torno da linguagem, e o aluno, frente a uma posição de autoritarismo, entra em um círculo de relações totalmente destituído de sentido e, em virtude disso, não aprende. Segundo Berberian, Mori-de Angelis e Massi (2006, p. 30):

Os clínicos da linguagem têm obrigação de denunciar tal realidade e de não compactuar com ela, substituindo um olhar simplista e homogeneizante por uma conduta politicamente comprometida com a transformação social. Para isso, é preciso se libertar das amarras de métodos clínicos pautados pela doença e pela norma e aderir a uma clínica verdadeiramente terapêutica, na qual o sujeito e sua história individual, e ao mesmo tempo profundamente social, sejam considerados até as últimas conseqüências.

\footnotetext{
${ }^{4}$ Nosso objetivo, neste estudo, não é discutir o diagnóstico fonoaudiológico em linguagem escrita, mas apontar algumas questões referentes ao tema para fundamentarmos a nossa atuação.
} 
Em vista da enorme demanda pelos serviços da clínica fonoaudiológica, acreditamos, por aspectos que acabamos de mencionar, que os gêneros do discurso podem ser objetos de trabalho voltados para sujeitos com "distúrbios de leitura e escrita”. Assim, preconizamos que, através das relações de sentido que a teoria bakhtiniana propõe, é possível reverter o quadro de instabilidades decorrentes de relações sofríveis com a modalidade escrita da linguagem.

O objetivo desta pesquisa é apresentar um estudo de caso de atuação fonoaudiológica centrada na teoria dos gêneros do discurso de Bakhtin. Para isso, analisamos crônicas produzidas por um grupo de três adolescentes que estão em processo terapêutico ${ }^{5}$ por apresentarem relações pouco significativas com a linguagem escrita. Pretendemos com tal análise, explicitar as contribuições da teoria de gêneros na condução dos procedimentos fonoaudiológicos para com os sujeitos considerados portadores de dificuldades de leitura e escrita.

\section{REFERENCIAL TEÓRICO}

A seguir, apresentamos alguns pressupostos teóricos que fundamentam nossa atuação. Salientamos que a adoção de uma concepção enunciativo-discursiva de linguagem advém da rejeição a teorias ${ }^{6}$ que relativizam a história do sujeito bem como a função social/interacional e ideológica da linguagem.

\subsection{A concepção dialógica da linguagem}

É a partir das considerações a respeito da realidade fundamental da linguagem que Bakhtin (2006[1929]) realiza uma crítica severa a duas correntes da lingüística: o subjetivismo idealista e o objetivismo abstrato. A primeira vertente interessa-se pelo ato de fala, reduzindo o fenômeno lingüístico a uma criação individual. A fonte da língua o psiquismo - é tomada como inerente ao indivíduo. O autor considera que, nesta corrente epistemológica, a criação lingüística é equiparável à criação artística e que a língua, enquanto sistema fechado e estável, apresenta-se como um “depósito inerte”, construída de forma abstrata como um objeto pré-concebido e, portanto, pronto para ser utilizado pelos falantes.

A segunda grande orientação do pensamento lingüístico-filosófico é, como já mencionado, o objetivismo abstrato. De acordo com Bakhtin (2006 [1929]), o fundamento desta tendência reside na consideração da língua enquanto sistema de formas abstratas e estáveis (fonologia, fonética, semântica, sintaxe, morfologia) ${ }^{7}$. A língua, sob esse enfoque, não está sujeita aos atos de criação individual; a fala não é o foco de estudo. Existiriam, assim, "traços idênticos" (identidade normativa das formas lingüísticas) presentes em todas as enunciações. O sistema da língua delineado dessa forma desconsidera qualquer ato individual/intencional de fala. O indivíduo é tomado como um ser passivo na medida em que recebe um sistema já constituído socialmente e

\footnotetext{
${ }^{5}$ Importante esclarecer que esta pesquisa representa um recorte terapêutico de um processo em andamento.

${ }^{6}$ Referimo-nos a teorias como o cognitivismo internalista, por exemplo.

7 Estes termos estão atualizados. Bakhtin (2006, p. 79) refere “[...] o sistema de formas fonéticas, gramaticais e lexicais da língua”.
} 
imutável (do ponto de vista sincrônico). A língua-sistema (BAKHTIN, 2006 [1929], p. 81) é regida por leis "puramente imanentes e específicas, irredutíveis a leis ideológicas, artísticas ou quaisquer outras”.

Talvez a questão mais marcante para Bakhtin com relação às concepções do que ele nomeou de objetivismo abstrato seja a questão histórica (diacronia x sincronia). $\mathrm{O}$ autor não admite pensar a língua desvinculada de seu uso, por isso torna-se impossível apartála de sua história e da evolução que a historicidade pressupõe. Assegura que a linguagem em uso pode, muitas vezes, determinar a própria norma lingüística. O autor adverte que são justamente os atos de fala individuais que explicam a variação histórica das formas da língua. Tais atos seriam, para o objetivismo, algo como deformações da norma ou pequenas variações sem conseqüências. "Entre o sistema da língua e sua história não existe nem vínculo nem afinidades de motivos. Eles são estranhos entre si.” (BAKHTIN, 2006 [1929], p. 85). Dessa forma, ao priorizar o sistema da língua, o objetivismo não consegue explicar o funcionamento da linguagem, já que os sujeitos se relacionam por enunciados concretos e não por meio de um sistema abstrato de formas lingüísticas.

O que Bakhtin nos diz com a crítica a essas duas correntes está relacionado à redução que tais postulados realizam em torno da linguagem. O subjetivismo idealista delega ao indivíduo o aporte da linguagem; a função da língua fica restrita à expressão de aspectos interiores. O fator mais relevante é a mente em funcionamento. Bakhtin, no entanto, assegura que não existe pensamento sem material semiótico, por isso o ato de fala ${ }^{8}$ só pode ser originado a partir das relações sociais nas quais o sujeito esteja inserido. Do mesmo modo, o objetivismo abstrato, ao enaltecer um sistema pronto e acabado, apartado de seu conteúdo ideológico e social, também não dá conta da realidade da língua, que é para Bakhtin a atividade dialógica (a interação verbal).

O diálogo, no sentido estrito de termo, não constitui, é claro, senão uma das formas, é verdade que das mais importantes, da interação verbal. Mas pode-se compreender a palavra diálogo num sentido amplo, isto é, não apenas como a comunicação em voz alta, de pessoas colocadas face a face, mas toda comunicação verbal, de qualquer tipo que seja. (BAKHTIN, 2006 [1929], p.127).

O autor continua seu raciocínio, citando o livro (enunciado impresso) como um dos elementos da comunicação verbal, já que é produzido para ser apreendido de forma ativa, ou seja, para ser objeto de reflexão e crítica por parte do leitor. Durante a leitura, autor e leitor estão em um diálogo a distância. "O discurso escrito é de certa maneira parte integrante de uma discussão ideológica em grande escala: ele responde a alguma coisa, refuta, confirma, antecipa as respostas e objeções potenciais, procura apoio, etc.” (BAKHTIN, 2006 [1929], p. 128)

É essa busca por um outro enfoque para o entendimento do fenômeno da linguagem que faz com que Bakhtin critique de forma tão árdua as concepções do subjetivismo e do objetivismo, que, embora divergentes entre si, desconsideram o dialogismo, que, para o autor, é crucial. É justamente por considerar que a linguagem não está nem dentro

\footnotetext{
${ }^{8}$ Bakhtin rejeita a tese da explicação do ato da fala a partir de condições psicofisiológicas do sujeito falante. A natureza do enunciado é eminentemente social.
} 
(psiquismo) nem fora (sistema abstrato de formas imutáveis) do indivíduo, e sim na intersubjetividade das relações, que recorremos a Bakhtin. Esmiucemos um pouco mais as considerações a tais correntes.

O autor critica o subjetivismo, revelando que se trata de uma visão equivocada do complexo processo que envolve a relação discursiva. O falante não pode ser reduzido a um simples emissor de um ato de fala, tampouco o ouvinte pode ser tomado com um receptor passivo de mensagens. Ao contrário, o "receptor", , ao ouvir e compreender um enunciado, adota para consigo uma atitude responsiva, quer dizer, ele pode concordar ou não, pode completar, discutir, ampliar, direcionar; enfim, atuar de forma ativa no ato enunciativo. Aliás, o locutor não deseja uma reação passiva, mas um retorno, uma vez que age no sentido de provocar uma resposta, atua sobre o outro, buscando convencê-lo, influenciá-lo.

Essa posição responsiva se forma durante todo o processo de escuta da fala alheia, na medida em que o ouvinte vai compreendendo e formando sua opinião a respeito do que está sendo ouvido; toda compreensão suscita uma resposta e a gera obrigatoriamente (o receptor torna-se locutor). É claro que essa responsividade se manifesta de formas variadas; a resposta pode ser uma ação a um pedido do locutor, pode ser um suspiro, um grito, um ato de silêncio ${ }^{10}$. Também pode ser, conforme Bakhtin, uma compreensão ativa de efeito retardado, conseqüência de leituras realizadas, por exemplo.

Ademais, o sujeito que fala é um "respondente" em potencial, já que o enunciado representa um elo na relação discursiva. O enunciado (BAKHTIN, 2003 [1952-1953]) é uma resposta a outros enunciados que já foram produzidos em outras situações interacionais, ou seja, o ato de fala é atravessado por outros discursos: "baseia-se neles, polemiza com eles, simplesmente os pressupõe já conhecidos do ouvinte” (p. 272).

Para Bakhtin (2006 [1929]), o sistema da língua, na realidade, serve a propósitos relacionais na medida em que é utilizado pelo locutor na construção de seus enunciados (sempre em um contexto ideológico preciso). O que vale não é a forma em si, mas a significação que ela recebe em uma situação interacional. Em outras palavras, a forma não tem relevância enquanto "sinal estável e sempre igual a si mesmo", mas importa enquanto signo flexível e mutante.

O sinal existe na língua, mas não a constitui. Bakhtin (2006 [1929]) diz que, na apropriação e no uso da língua materna, o sinal e o reconhecimento estão relativizados, mas que esse processo de apagamento não ocorre na aquisição de uma língua estrangeira, quando “[...] a língua ainda não se tornou língua. A assimilação ideal de uma língua dá-se quando o sinal é completamente absorvido pelo signo e o reconhecimento pela compreensão" (p. 97). Podemos refletir sobre essa passagem e transpô-la à mediação no processo de ensino da língua materna escrita. A língua só faz sentido quando em uso e na prática viva desse uso; assim, uma palavra "ensinada" a uma criança, desvinculada de seu contexto interacional, não passa de um sinal, desprovida de valor lingüístico. Pensamos, então, com Bakhtin, que a forma deve ser

\footnotetext{
${ }^{9}$ Atentemos ao sentido da palavra.

${ }^{10}$ Ao assistirmos a uma ópera, em geral, somos coagidos a responder em silêncio.
} 
apresentada não no sistema abstrato da língua, mas "[...] na estrutura concreta da enunciação [...]" como um "[...] signo flexível e variável [...]”. Isso vale também para nós, fonoaudiólogos ${ }^{11}$, e a opção pelos gêneros do discurso como objetos terapêuticos dá-se em função dessas concepções em torno da linguagem.

\subsection{Os gêneros do discurso}

Tão “multiformes” quanto o uso da língua são os diversos domínios da atividade humana. Os interagentes em tais domínios, durante a comunicação discursiva, empregam a língua por meio de enunciados. Estes, por sua vez, emanam as finalidades de cada esfera à qual estão relacionados, e isso se reflete em seus constituintes (tema, construção composicional $^{12}$ e estilo $^{13}$ ), conforme Bakhtin (2003 [1952-1953]). Esses elementos estão inter-relacionados e são determinados em virtude de certos aspectos presentes nas esferas de atividade. Segundo o autor, cada enunciado é singular, mas cada domínio de atividade elabora "[...] seus tipos relativamente estáveis de enunciados ${ }^{14}$ os quais denominamos gêneros do discurso.” (p. 262).

A palavra tipos se refere a uma "tipificação social” dos enunciados que denotam certas regularidades em comum, que foram se constituindo historicamente, segundo Rodrigues (2005), nos domínios humanos, em determinadas situações interacionais relativamente estáveis. Essa tipificação é detectada/reconhecida pelos sujeitos falantes. Dessa maneira, somente nas situações de interação, isto é, nas esferas de atividade, é possível que se apreenda a formação e o funcionamento dos gêneros. A autora exemplifica tal colocação da seguinte forma: tomemos os gêneros biografia científica e romance biográfico; apesar de demonstrarem traços de regularidades comuns (princípio que organiza a narrativa que conta a história de vida de alguém), estão vinculados a campos de atividade distintos, com funções discursivas e ideológicas também distintas; nesse caso, mesmo mantendo traços comuns, estamos diante de dois gêneros diferentes, daí a necessidade de considerarmos a esfera de circulação do gênero para que compreendamos sua constituição e real funcionamento.

Rodrigues (2001) diz que os gêneros configuram-se em “índices sociais” de regulação e construção do enunciado (de onde falo, para quem falo, com que intenção, de que lugar social, como sou visto pelo meu interlocutor, que estratégias vou usar para falar etc.). Já para o interlocutor, o gênero determina um "horizonte de expectativas" em relação ao enunciado alheio, favorecendo a previsão de alguns aspectos como a extensão do enunciado do locutor, sua composição, sua expressividade etc. A própria inferência do gênero, para o interlocutor, já representa um fator, que, unido aos citados anteriormente, perfaz a constituição dos sentidos do enunciado.

\footnotetext{
${ }^{11}$ Não apenas para professores de línguas.

12 "Procedimentos composicionais para a organização, disposição e acabamento da totalidade discursiva e da relação dos participantes da comunicação discursiva” (RODRIGUES, 2005, p. 167).

$13 \mathrm{O}$ estilo corresponde à seleção individual de recursos da língua: composição vocabular, frasal e gramatical.

${ }^{14}$ Tipos social e historicamente determinados. Bakhtin compreende os gêneros a partir da sua historicidade e, assim, atribui-lhes natureza idêntica a do enunciado: discursiva, social, dialógica e ideológica.
} 
Assim, a construção do enunciado, mesmo levando em conta a intenção discursiva, não pressupõe o uso absolutamente livre das formas da língua. Para a interação, se faz necessário o domínio do gênero para além do domínio das formas da língua (RODRIGUES, 2005). A autora refere que os gêneros são bem mais plásticos e sensíveis ao fator histórico do que as formas da língua, mas isso não implica que estas sejam apreendidas antecipadamente pelos falantes.

Adquirimos as formas da língua, segundo Bakhtin (2003 [1952-1953]), em conjunto com as formas do gênero. A apropriação da fala ocorre a partir da inserção em situações interativas de uso da linguagem; a própria sintaxe da língua falada é adquirida na comunicação discursiva usual. O autor segue salientando que a aquisição da fala implica a aprendizagem de enunciados, pois as relações ocorrem por meio de enunciações concretas e não pelo emprego de palavras e orações abstratas ${ }^{15}$. A própria escuta da fala do outro já pressupõe (como já dito) o gênero utilizado; sua extensão, sua composição, seu fim; conseguimos apreender a intenção discursiva alheia pelo gênero em uso. O autor diz que, se tivéssemos que criar o gênero pela primeira vez, se não o dominássemos, se não possuíssemos habilidades para o seu emprego de forma natural, a comunicação via discurso seria bastante difícil.

Não é possível que façamos uma contagem dos gêneros devido ao seu número ilimitado. Isso se deve à grande diversidade de esferas existentes e, sobretudo, ao caráter de complexificação de cada esfera. Assim, à medida que um certo domínio se desenvolve, vão surgindo novos gêneros que se constituem e se estabilizam historicamente, em um processo ininterrupto.

Devido a essa enorme heterogeneidade, Bakhtin (2003 [1952-1953]) realizou uma divisão dos gêneros, separando-os em primários e secundários. Os primários aludem às situações interacionais cotidianas, espontâneas, não-elaboradas, que sugerem uma comunicação imediata. São exemplos de gêneros primários a carta, o bilhete, o diálogo cotidiano. Os gêneros secundários, principalmente mediados pela escrita, aparecem em situações mais complexas e elaboradas de interação social, como em teatro, romance, tese, palestra, telejornal etc. O que os diferencia (primários e secundários) é o nível de complexidade em que se apresentam. No processo de formação dos secundários, ocorre absorção e reelaboração dos primários. Dessa maneira, o diálogo cotidiano relatado no romance (intercalação) perde seu caráter imediato e passa a incorporar as características do universo narrativo (complexo) que lhe deu origem; ou seja, nessa situação, o diálogo transforma-se em acontecimento literário e deixa de ser cotidiano. Apesar da imensa heterogeneidade dos gêneros, eles possuem algo em comum, a saber: a natureza verbal (socioideológica e dialógica).

Como este artigo relaciona-se ao trabalho específico com a crônica, teceremos, na próxima seção, breves comentários acerca desse gênero secundário.

\footnotetext{
${ }^{15}$ Palavras e orações, tomadas em sua forma abstrata, não são ditas para ninguém, carecem de qualquer relação com o dizer do outro, e só quando inseridas em uma situação discursiva é que passam a representar a intenção do sujeito, tornando-se, assim, um enunciado, com toda a concretude que este supõe.
} 


\subsection{A crônica}

Segundo Bussarello (2004), a crônica denota um certo hibridismo, pois apresenta mescla de jornalismo e literatura. Tal fato advém de sua origem naqueles espaços reservados às "variedades textuais" nos antigos folhetins. Os textos ali expostos, incluindo os romances capitulados, não tinham um caráter jornalístico propriamente dito, figuravam como forma apenas de entretenimento. O autor refere que é possível percebermos reflexos desse fenômeno através de marcas literárias deixadas em algumas crônicas atuais; no entanto, a despeito de seu processo histórico, a crônica é enquadrada em um gênero da esfera jornalística, o que não impede que encontremos crônicas compiladas em livros, perdendo, dessa forma, sua ligação com os acontecimentos atuais.

Bussarello (2004, p. 74) diz que a crônica:

[...] parece ser um dos gêneros em que é possível uma maior riqueza de uso de características que também se observam nos gêneros literários, como a ironia, o humor, o estilo de vezo individual, porque nos parece que no próprio estilo do gênero crônica fica embutida essa potencialidade de estilo individualizado do autor.

O cronista tem a capacidade de transformar um assunto aparentemente desinteressante em uma reflexão sociopolítica de cunho humanístico, abrangendo as condições de milhares de pessoas. É um escritor que pode tratar de um assunto sério com revestimentos irônicos ou engraçados, sempre embuídos em uma nuance ideológica. Aliás, o cronista maneja muito bem os aspectos de humor e ironia em seus textos; é como se eles fossem criados com o objetivo de entretenimento, talvez por isso sua ligação com a área literária (MACHADO apud BRAYNER, 1992).

Apresentados alguns fundamentos, passaremos à apresentação do caso e, na seqüência, da forma de atuação específica com o gênero crônica (metodologia).

\section{APRESENTAÇÃO DO CASO}

Os sujeitos da presente pesquisa, denominados pelas iniciais A.S., H.D. e J.F., realizam atendimento fonoaudiológico em grupo no "ambulatório de leitura e escrita" de um hospital no município de Florianópolis. Os três adolescentes foram encaminhados para avaliação por apresentarem, segundo parecer escolar, dificuldades na leitura e na escrita (interpretação e produção textuais). As questões mais relevantes levantadas nos relatórios denotavam preocupações relativas a aspectos formais da escrita como erros demasiados de ortografia e de segmentação, e a falta de interesse por parte dos alunos por atividades que envolviam a leitura e a escrita. A seguir, constam alguns trechos contidos nos relatórios: “[...] recusa-se a ler em voz alta [...]”, “[...] não realiza perguntas [...]”, “[...] não completa os deveres de casa [...]”, “[...] não participa da aula [...]”, “[...] apresenta falta de concentração [...]”, “[...] é agressivo com os colegas [...]”. Tais questões não serão aprofundadas por considerarmos que o “discurso escolar" é sempre previsível e redundante: impõe a palavra de uma instituição que exclui ao invés de acolher, e que vê no encaminhamento à clínica uma fonte de desculpabilização em relação aos problemas de escrita apresentados pelos alunos. 
A.S. é uma adolescente de 16 anos de idade. Convive com seus pais e um irmão em um município do interior de SC. Os pais são agricultores e possuem instrução escolarizada precária; portanto não possuem hábitos de leitura e escrita. Mesmo assim, a mãe declara que, por vezes, tenta anotar alguma receita de culinária. Quando questionados em relação à possível causa dos problemas de escrita da filha, salientaram que esta passou da hora de nascer: "chegou a beber a água do parto”. A.S. atualmente freqüenta a sétima série do ensino fundamental em uma escola da rede pública. Teve muita dificuldade na aprendizagem da leitura, tendo sido reprovada várias vezes, sobretudo, nas séries iniciais. A.S. está em processo terapêutico desde julho de 2007. No início do processo, a estudante apresentava crises depressivas: "[...] ela fica gelada e se esconde, fica calada; estou preocupada [...]" (discurso da mãe), tendo recebido avaliações de outros profissionais. Na realidade, a menina apresentava uma auto-imagem bem rebaixada: “[...] não agüento mais ser chamada de burra, de idiota; só porque tenho problema [...]”, tinha poucas amizades, era introspectiva e denotava uma relação negativa com a escrita, razão pela qual foi aceita para atendimento. A terapia centrou-se em uma concepção dialógica de linguagem, processo em que uma das questões relevantes foi o trabalho voltado para a ressignificação da queixa.

Quanto a H.D., é um adolescente de 15 anos de idade que freqüenta a sexta série do ensino fundamental em uma escola pública da capital de Santa Catarina. Seus pais são separados, e ele vive com a mãe e a irmã. O pai é alcoólatra e pouco se importa com os filhos, conforme as palavras da mãe, a qual estudou até a oitava série do ensino fundamental e diz ter o hábito da leitura: “[...] quando posso, leio romances.” Na realidade, ela, por vezes, fica aguardando o filho na sala de espera com um livro na mão. H.D. mostrou-se um menino extrovertido desde o início do processo terapêutico, no entanto sua mãe salienta que o filho só começou "a se soltar" depois que o pai saiu de casa. No início da terapia, em agosto de 2007, esse fato já tinha ocorrido havia dois anos, mas, mesmo se mostrando um menino descontraído e de bem com a vida, H.D. apresentava certo sentimento de repulsa em relação à escrita: “[...] ler não, por favor!”, "Escrever? Ih... pior ainda"; por vezes, comentava alguns traumas que havia desenvolvido na escola: "[...] ela [uma professora] fez uma bolinha no quadro e me obrigou a ficar com o nariz ali [...]”, “[...] ela [a mesma professora] disse que eu não iria dançar na festa junina, como castigo por nunca fazer a lição.” Sua mãe apresentava uma posição de passividade em torno do discurso escolar: “[...] eles dizem que ele tem problema, eu faço meu papel - trago aqui - mas, para mim, ele não tem nada, só preguiça, muita preguiça. Ah, eu também era assim [...]”.

J.F., por sua vez, tem 16 anos e está na sexta série do ensino fundamental. Seu pai é pescador e estudou até a terceira série. Sua mãe é do lar e cursou até a quarta série e, mesmo com pouca escolarização, mostra-se muito participativa em relação ao desenvolvimento do filho. Sempre está na escola, questionando os professores sobre o desempenho de J.F., apresentando-se disposta a atender a todas as orientações recebidas. $\mathrm{O}$ adolescente nunca faltou a um atendimento sequer desde o seu início, em outubro de 2007. Além disso, costuma realizar todos os trabalhos de leitura e escrita que são solicitados para casa. J.F., quando teve início o atendimento, apresentava o discurso típico de sujeitos em situação de avaliação: "Não sei.”, "Não consigo” e, quando escrevia um texto, já ia antecipando o enunciado da terapeuta: “Tá tudo errado, já sei!”. J.F. tem um professor de Língua Portuguesa considerado "muito bom” pelos familiares 
do aluno e por outros profissionais da escola; no entanto, certa vez, quando questionado a respeito, J.F. disse: "Bom ele é, só que eu não gosto muito é que ele dá coisa diferente dos outros pra mim e pra T.” T. é colega de turma de J.F. e também é atendida pelo nosso serviço. A pouca auto-estima de J.F. e sua relação problemática com a escrita fizeram com que ele fosse aceito para o atendimento fonoaudiológico.

Vale comentar que os sujeitos desta pesquisa foram selecionados levando-se em conta alguns critérios: ausência de alterações sensoriais importantes (auditivas, visuais), ausência de alteração cognitiva e problemas emocionais graves - no momento em que se deu a pesquisa (receberam avaliação psicológica) -, assiduidade às sessões, interesse em participar do estudo e, por fim, permissão dos pais para que os dados de seus filhos fossem divulgados. A avaliação fonoaudiológica recebida por eles esteve pautada em uma concepção constitutiva de linguagem. Suas produções textuais, focadas por dimensões discursivas, revelavam que nenhum dos três adolescentes apresentava distúrbios de linguagem escrita, pois seus textos cumpriam a função primordial de imprimir sentidos ao leitor ${ }^{16}$. Assim, a aceitação para a terapia deu-se em virtude, como já relatamos, da queixa apresentada pelos familiares ${ }^{17}$, da auto-estima abalada dos adolescentes e da relação de sofrimento com a escrita que acabou por gerar reflexos negativos em suas práticas de letramento escolarizadas.

\section{METODOLOGIA}

Os adolescentes recebem atendimento fonoaudiológico em grupo; freqüentam o mesmo grupo de terapia que é realizada uma vez por semana. A duração do atendimento costuma ser em média de sessenta minutos. Durante as sessões, envoltas por contextos significativos de uso da língua, os adolescentes escrevem, lêem, posicionam-se em relação aos assuntos tratados, sugerem gêneros a serem trabalhados etc. Dessa forma, a interlocução é permeada por uma situação dialógica, na qual a terapeuta coloca-se em uma posição de mediadora, e os sujeitos em uma posição responsiva ativa.

Salientamos que o processo terapêutico voltado para a imersão do sujeito em práticas sociais - tomando por fundamento as considerações acerca da teoria bakhtiniana -, não pode,-segundo nosso ponto de vista, ser realizado de forma superficial. Assim, a simples visitação aos gêneros ${ }^{18}$ não configura a real profundidade que a proposta requer. Não precisamos eleger muitos gêneros durante a condução do processo, nem teríamos tempo terapêutico suficiente para isso; o importante é fazer com que o indivíduo aprenda a se apropriar de determinadas práticas sociais de leitura e escrita. O sujeitos, ao ser conduzido na "apropriação" de um determinado gênero, necessita passar por um período de "experimentação" (vivência) com esse mesmo gênero, para que consiga apreender suas características, suas dimensões constitutivas (verbal e extraverbal). Na realidade, não objetivamos formar cronistas, romancistas, articulistas; longe disso, esperamos

\footnotetext{
${ }^{16}$ Concebemos os sujeitos, à luz da teoria bakhtiniana, como constituídos na/pela linguagem, por meio de suas interações sociais; assim, pudemos perceber que os textos dos adolescentes não representavam um "sintoma” de linguagem, mas, sim, reflexos de seu percurso histórico, conseqüência do pouco/ineficaz contato com o objeto escrito.

${ }^{17} \mathrm{Na}$ realidade, a queixa da família reflete o discurso da escola. Os pais já chegam à primeira sessão "munidos" de um encaminhamento escolar.

${ }^{18}$ Preconização dada pelos fonoaudiólogos que tomam os gêneros como objeto terapêutico.
} 
tornar o sujeito "proficiente" em gêneros para que ele saiba se colocar ativamente frente a situações que impliquem a produção e a compreensão de textos (gêneros) variados; que consiga minimamente reconhecer alguns gêneros pela leitura; e que possa estender seu aprendizado para outros gêneros, quando necessário (em virtude de necessidades referentes à vida escolar/acadêmica, privada, profissional).

A crônica foi um dos gêneros selecionados para o atendimento devido ao sucesso que faz entre os adolescentes. E, como um dos objetivos da clínica é conquistar leitores/produtores de textos através de relações prazerosas com o objeto escrito, optamos por esse gênero com o intuito de aproximar os alunos da linguagem em meio a contextos significativos e interessantes.

Dessa maneira, seguimos a metodologia proposta por Bussarello (2004) para o trabalho com as crônicas:

1. seleção de crônicas (corpus);

2. leitura - entretenimento do gênero;

3. leitura analítica do gênero com posterior comparação com outros gêneros (notícia, artigo, resenha);

4. produção de crônicas;

5. divulgação dos textos.

Com relação ao item 1, selecionamos doze crônicas, obtidas em um jornal de grande circulação e também de coletâneas. Primamos por uma autoria heterogênea, para que os sujeitos percebessem as diferenças de estilo dos escritores. A escolha levou em conta faixa etária dos integrantes do grupo, além de estilo e composição textuais.

As leituras descontraídas (item 2), sem que se fizesse qualquer menção às dimensões do gênero, foram realizadas em três sessões de terapia. Depois, as leituras reflexivas/analíticas (realizadas com as mesmas crônicas já lidas) estenderam-se por mais quatro sessões. Durante a leitura, foram enfatizados alguns aspectos que, de acordo com Bussarello (2004), favorecem a tomada de reflexão por parte do estudante. Assim, alguns questionamentos foram realizados como os que se seguem: De que trata a crônica? Qual sua finalidade? Qual o assunto? Qual o tom expressivo do texto: ironia, humor, ou ambos? Há relação entre o título e o desenvolvimento do texto? Quem escreveu? Para que público escreveu? Em que veículo escreveu? As comparações com outros gêneros foram realizadas para que os adolescentes percebessem algumas diferenças constitutivas entre eles; desse modo, apresentamos textos variados para que eles simplesmente dissessem se se tratava ou não de uma crônica.

Por fim, foram necessárias três sessões para a prática de produção textual (incluindo revisão e reescritura dos textos). Nesse quesito, também seguimos as sugestões de Bussarello (2004) e propusemos algumas questões para que servissem como "guia” para a escritura dos textos (após o surgimento das idéias iniciais): Qual o leitor provável da sua crônica? Qual é o objetivo da sua crônica? Que assunto será abordado? Qual o veículo divulgador de sua crônica? Qual o tom que você dará à crônica: ironia, humor ou ambos? Como será a composição do texto? Terá diálogo? Com que objetivo você fará tal montagem? O título é sugestivo? Há relação entre este e o desenvolvimento do texto? Haverá ilustração? Há relação entre esta e o texto verbal? 
Depois de produzidos, os textos passaram por um processo de reescritura, que aconteceu de forma individual (cada um com seu próprio texto) e em grupo, etapa em que cada integrante leu a crônica do colega, realizando observações orais ao final. A terapeuta mediou todo o processo, realizando intervenções/considerações diretas. A atenção dos sujeitos foi direcionada principalmente para os aspectos de coerência e coesão textuais, ortografia, pontuação, paragrafação e concordância. A adequação ao gênero não apresentou problemas nos textos, já tendo sido focada durante o processo de produção dos mesmos.

Cada adolescente produziu um texto durante o procedimento terapêutico relacionado com as crônicas. Para isso foram necessárias dez sessões de terapia fonoaudiológica, como já mencionado, que se estenderam do período de maio a agosto de 2008 (com intervalo em julho). Os textos foram produzidos para serem expostos no mural da sala de espera do ambulatório do hospital onde se dá o atendimento ${ }^{19}$. Após a exposição por uma semana, foram recolhidos para serem divulgados em uma revista que estávamos organizando.

\section{RESULTADOS}

A seguir apresentamos os textos produzidos pelos adolescentes em sua versão final, preservando palavras e escritura dos autores.

\section{Produção textual de J.F.:}

\section{O Concentrado}

Meu pai é daquele tipo de pessoa que adora viajar, é um tremendo viajão!

Certa vez estávamos indo viajar para o RS no nosso carro e uma família de amigos estava no carro deles. O carro deles ia na frente e o nosso seguindo atráz. Tava indo tudo bem, quando, de repente, minha mãe falou:

Nossa, olha como eles diminuíram o ritimo!

Acho que é porque as crianças durmiram, disse o meu pai.

Na verdade, as duas cabecinhas tinha desaparecido.

As horas iam passando, ou melhor, não passavam. O calor matando e nada das cabecinhas aparecerem...

Oh pai passa essa criatura, pelo amor de Deus!

Melhor não, ele vai achar que eu to achando ele devagar. Não sei porque diminuíram tanto, devem estar a sesenta, quando fizerem uma parada eu passo.

E foi indo, indo, até que, por nossa senhora, eles pararam no acostamento. Meu pai parou um pouco mais a frente.

Foi quando olhamus para tráz...

Do carro saem uns japas, nunca tínhamos visto eles antes.

Meu Deus, não eram eles! (os nossos amigos)

E o pior é que meu pai ainda se acha o concentrado. Eu, hein!

19 Alguns textos produzidos pelos pacientes vão para exposição no mural na sala de espera do ambulatório. Lá, familiares, adolescentes e crianças aguardam, às vezes por bastante tempo, à espera de atendimento médico. Como não existem revistas ou outro material que os entretenha, surgiu a idéia do mural. 


\section{Produção textual de H.D.:}

\section{Quem ri por último...}

Tati era a menina mais bonita da sala, da escola, do bairro, do mundo!

Mas ela mal me via, só tinha olhos para o Afonso, aquele do cabelinho lambido, tão fofo...

Certo dia tomei coragem e decidi convidar a gostosa pra "cume uns pastel."

E aí Tati, vamu no cinema?

E ela me olhando de cima me deu a maior esnobada:

Era só o que me faltava!

O Afonso e toda a escola ficou sabendo do ocorrido, ele sempre tão fofo também não deixo quieto, claro tava afim dela:

Aí irmão, como é que tu teve coragem de chamar a Tati para sair? Dei tanta risada...

Aliáis, com ele a estória era bem diferente. Era só sorrizinho e mensagem de celular.

Até que os dois começaram a namorar.

Um dia eu tava em casa quando a mãe do Afonso veio pedi uma xícara de açúcar para faze um bolo. Eles eram nossos vizinhos.

Depois mais tarde a D. Ziza, este era o nome dela, veio trazer um pedaço de bolo para minha mãe e as duas ficaram conversando na sala:

Ai Salete, ando tão preocupada com o Afonso.

Porque Ziza, ele tá com alguma coisa? tá doente?

Não, mas não quer saber de toma banho por nada, chega a ficar 4, 5 dias sem entrar embaixo do chuveiro, diz que não vai morre por causa disso.

Ziza, como é que pode? Um rapaz tão bonito... Porque será?

No dia seguinte, na escola, tava lá a Tati se esfregando no Afonso.

Pensei comigo: "ah, se ela soubesse...”

\section{Produção textual de A.S.:}

\section{O Tímido}

O tímido é alguém que tem muita vergonha, tem medo de tudo, morre de medo de gente, morre de medo de levar um tombo ou falar alguma bobagem e todo mundo rir dele. Também tem timides de apresentar trabalho lá na frente. Na verdade, é melhor não ser tímido porque se cair ninguém ri, ou ri, mas ele não liga, quer dizer, faz que não liga, né?

A seguir realizaremos algumas análises e reflexões acerca dos resultados.

\section{DISCUSSÃO}

Ao início da produção textual, estavam os três adolescentes e a terapeuta (T) sentados ao redor de uma mesa redonda. Os papéis ainda em branco...

A.S. - Sabe T, não tenho a menor idéia do que escrever...

H.D. - Eu também não! 
J.F. - Esse troço tá ficando muito difícil... Tem que ficar pensando muito... A cabeça tá vazia!

T. - Gente, será que é tão difícil assim... Pensem em alguma coisa engraçada que já aconteceu com vocês... Ou se inspirem em alguma coisa que vocês já leram, já viram, já ouviram, já assistiram... Vocês acham que os autores tiram as idéias da onde? O que poderia dar uma crônica? Pensem...

A.S. - Meu Deus, todo mundo vai ler depois, não dá para ficar inventando qualquer coisa. A mãe do W. tá de olho em mim... Fica lendo lá no mural tudo que eu escrevo... (W. é um "amigo" dela e também é atendido por nosso serviço) ${ }^{20}$.

Começaram a se lembrar de coisas, contavam para o grupo, riam, davam sugestões à idéia do outro e, assim, as letras começaram a preencher o papel à frente deles.

O texto de J.F. foi uma história verdadeira que aconteceu com ele. A família estava indo viajar com amigos para o Rio Grande do Sul, e o pai, distraído, ficou três horas atrás de outro carro achando que era o do amigo. J.F. conta que não conseguiram (os outros que estavam no carro) perceber também o "equívoco" porque o carro da frente era igual ao dos amigos deles e também por causa da distância que o pai, precavido, mantinha. J.F., então, comentou: "Quando você disse para pensarmos em algo engraçado que aconteceu com a gente, não teve outra, porque naquele dia ficamos rindo por mais três horas [...]" O pai de J.F., apesar de vir atrás dos "amigos" (do que ele achava, pelo menos, que fossem os amigos), quando da parada deles, colocou o carro bem adiante na estrada, porque queria sair na frente deles depois. J.F. especifica essa passagem no texto.

A crônica de J.F. apresenta um tom humorístico convincente. Também tem uma pitada de ironia, refletida na primeira passagem "[...] meu pai é daquele tipo de pessoa que adora viajar, é um tremendo viajão!”, também ao final do texto denota essa característica "[...] e o pior é que meu pai ainda se acha o concentrado [...]”. A propósito, esse tom está reforçado no título "O concentrado”, que acabou sendo uma sugestão nossa, pois o título original "O distraído" nos pareceu muito óbvio. J.F. resolveu aceitar a sugestão porque achou que resultaria em um melhor efeito estético para o seu texto: "Gostei, combinou com a parte final, quando chamo meu pai de concentrado (risos)". O humor ficou bem marcado no texto até pelo uso de expressões como: “[...] e foi indo, indo, até que, por nossa senhora, eles pararam no acostamento." (grifo nosso) Salientamos que tal expressão não é usada corriqueiramente na fala de J.F.; seu uso no texto deveu-se, muito provavelmente, ao caráter engraçado que queria conferir a sua crônica.

A crônica de H.D., como a de J.F., também imprimiu um sentido humorístico. Sua história é metade realidade e metade ficção (a parte ficcional foi a final, o que ele gostaria que realmente tivesse acontecido, digamos, uma espécie de revanche). Outras

\footnotetext{
${ }^{20}$ Este diálogo foi anotado pela terapeuta no momento da interação. Não houve gravação de áudio ou realização de filmagem durante o procedimento de coleta dos dados.
} 
questões relativas às condições de produção do texto também merecem alguns comentários. Na passagem em que ele revela "Certo dia tomei coragem e decidi convidar a gostosa pra [...]", na verdade, a sua "coragem" em chamar a menina para sair partiu de uma aposta que fizera com seus amigos da escola: “[...] eles duvidaram, então eu falei: se cada um der dois pila adiantado eu vou mesmo [...]”, e foi mesmo! Quando ele escreve: "E ela me olhando de cima me deu a maior esnobada [...]", façamos uma tradução literal: a moça é bem mais alta que ele, que por sinal, possui uma estatura abaixo da média. A partir do momento em que ele relata que a mãe do Afonso foi à casa dele, entra a imaginação pura. No texto, percebemos também tom irônico como em algumas passagens "[...] aquele do cabelinho lambido, tão fofo [...]”; “[...] ele sempre, tão fofo, também não deixo quieto, claro tava afim dela [..]” Também explora em seu texto reflexos do cotidiano, comum em crônicas: “[...] veio pedi uma xícara de açúcar [...]”; “[...] veio trazer um pedaço de bolo [...]" Conseguiu criar um diálogo para vizinhas (ao final do texto) com tamanha naturalidade, que dá a impressão de que a história é inteiramente real. Como um adolescente poderia impor à sua mãe uma fala dessas, bem típica de mãe: “Ziza, como é que pode? Um rapaz tão bonito... Porque será?” Apesar de a história ser triste, quer dizer, nem tanto, já que foi fruto de uma aposta, e considerando o fato de H.D ser bem engraçado e extrovertido, podemos notar que ele consegue impor o humor em vários momentos do texto: “[...] decidi convidar a gostosa pra cume uns pastel”; também na resposta da garota ao pedido do encontro: "Era só o que me faltava!”. Essa colocação pareceu dar um sentido humorístico ao discurso da garota, sinalizando sua recusa ao convite feito a ela; da mesma maneira, ao final do texto, temos um fechamento bem elaborado: "No dia seguinte, lá na escola, tava lá a Tati se esfregando no Afonso. Pensei comigo: ah, se ela soubesse”.

Com relação ao texto de A.S., percebemos que a adolescente baseou-se em uma das crônicas lidas: Da timidez, de Luiz Fernando Veríssimo. Como já mencionado, havíamos sugerido que eles buscassem inspiração em algo que tivessem ouvido, lido ou em episódio acontecido com eles, isso para evitar que tomassem as leituras como modelos a serem seguidos, mas acreditamos que, nesse caso, houve também um processo de identificação com a leitura ${ }^{21}$ daquele texto especificamente, já que A.S. é uma pessoa tímida. Assim, quando ela diz no texto: “Também tem timides de apresentar trabalho lá na frente.” está se referindo à sua realidade, porque ela não se sente à vontade na apresentação de seminários na escola. Dessa forma, A.S. apresentou o tema reportando-se às questões cotidianas. Para o final do texto, nós demos uma sugestão de acabamento. A versão original terminava assim: “[...] na verdade, é melhor não ser tímido porque se cair ninguém ri, ou ri, mas ele (o não tímido) não liga.” Com a nossa colaboração, o texto terminou da seguinte forma: "Na verdade, é melhor não ser tímido porque, se cair ninguém ri, ou ri, mas ele não liga, quer dizer, faz que não liga, né? (grifo nosso)

Percebemos, com a discussão apresentada, que os adolescentes conseguiram atingir seus objetivos com a escritura dos textos, ou seja, transmitiram relações de sentido por meio das características do gênero em questão. As crônicas apresentaram tons de ironia, humor e também revelaram questões cotidianas. Os integrantes do grupo colocaram-se como sujeitos do discurso sem se preocuparem exclusivamente com aspectos formais.

\footnotetext{
${ }^{21}$ Comum em crônicas devido aos temas abordados.
} 
As estratégias ${ }^{22}$ para causar o impacto pretendido em relação a um outro é que balizaram todo o processo de produção textual. Durante a escrita, as questões gramaticais, ortográficas e textuais foram requeridas como um suporte para a concretização da intenção discursiva dos sujeitos.

\section{CONSIDERAÇÕES FINAIS}

Ao término de nossa pesquisa, percebemos que existem questões importantes que não foram enfocadas ${ }^{23}$ e que haveria outras maneiras de trabalhar a produção textual (seqüências, tipologias, outras teorias de gêneros - como a do interacionismo sociodiscursivo do grupo de Genebra) - com os sujeitos que nos vêm encaminhados com "pré-diagnósticos" de distúrbios de escrita. Mesmo assim, finalizamos nossas considerações, momentaneamente, explicitando que acreditamos que o fonoaudiólogo que trata de supostas alterações de linguagem deva considerar o paciente-sujeito como um indivíduo que se constitui em suas interações sociais e que, a depender da qualidade dessas interações, poderá desenvolver uma visão distorcida a respeito de si mesmo ${ }^{24}$. Como nas palavras de Berberian (2006, p. 860):

É sob esse efeito de uma identidade estereotipada, dissecada por
discursos e conhecimentos que se pretendem científicos, que
processos de aquisição de escrita são abortados e, por conseguinte,
crianças são marginalizadas pelo estigma dos distúrbios de leitura. É
nesse contexto, de violência cultural e de exclusão social, que as
práticas fonoaudiológicas se inscrevem.

Assim, ao pensarmos em nossas atuações com esses sujeitos, eminentemente situados em uma posição de incapacidade (lingüística), temos o dever de redimensioná-la, e só o conseguiremos através da inserção do sujeito em eventos de letramento realmente significativos, permeados por mediações eficazes.

\section{REFERÊNCIAS}

BAKHTIN, M.. ,Marxismo e filosofia da linguagem. Tradução de Michel Lahud; Yara Frateschi Vieira. São Paulo: HUCITEC, 2006 [1929].

Os gêneros do discurso. In: BAKHTIN, M.. Estética da criação verbal. Tradução de Paulo Bezerra. São Paulo: Martins Fontes, 2003 [1952-1953]. p. 261-306

BERBERIAN, A. P.. Linguagem escrita no contexto da clínica fonoaudiológica. In: LOPES FILHO, O. Tratado de fonoaudiologia. São Paulo: Roca, 2006.

\footnotetext{
${ }^{22}$ Estratégias que dizem respeito à adequação ao gênero, com especial ênfase ao tom humorístico, a fim de provocar o riso no leitor.

${ }^{23}$ Tais questões são relativas ao processo terapêutico como um todo, que engloba aspectos referentes à ressignificação da queixa, fator que considera as interações nas quais o paciente se insere (família e escola, principalmente). Esses aspectos não foram enfocados por motivo de espaço e também porque fugiria ao objetivo deste trabalho.

${ }^{24}$ Notas de aula - Professora Dra. Ana Paula Berberian.
} 
BERBERIAN, A. P.; MORI DE-ANGELIS; MASSI, G.. Violência simbólica nas práticas de letramento. In.: . Letramento: referências em saúde e educação. São Paulo: Plexus, 2006.

BUSSARELLO, J. M. O ensino-aprendizagem da produção textual na perspectiva dos gêneros do discurso: a crônica. 2004 Dissertação (Mestrado em Lingüística) Universidade Federal de Santa Catarina, Florianópolis, 2004.

BRAYNER, S. Machado de Assis: um cronista de quatro décadas. In: A crônica, sua fixação e suas transformações no Brasil. Campinas: Editora UNICAMP, 1992.

RODRIGUES, R. H.. Os gêneros do discurso na perspectiva dialógica da linguagem. In: MEURER, J.L.; BONINI, A.; MOTTA-ROTH, D. (Org.). Gêneros: teorias, métodos e debates. São Paulo: Parábola Editorial, 2005.

A constituição e o funcionamento do gênero jornalístico artigo: cronotopo e dialogismo. 2001, Tese (Doutorado em Lingüística) - Pontifícia Universidade Católica, São Paulo, 2001. 


\section{ANEXO}

\section{Crônicas utilizadas durante o processo terapêutico:}

1. O marido da contorcionista, Luiz Fernando Veríssimo

2. Adolescência, Luiz Fernando Veríssimo

3. “Cãomício” no calçadão, José Carlos Oliveira

4. Já não se fazem pais como antigamente, Lourenço Diaféria

5. As aventuras de um ciclista urbano, Lourenço Diaféria

6. No país do futebol, Carlos Eduardo Novaes

7. Sexa, Luiz Fernando Veríssimo

8. Da timidez, Luiz Fernando Veríssimo

9. Assalto, Carlos Drummond de Andrade

10. O homem nu, Fernando Sabino

11. Marido e mulher, Paulo Mendes Campos

12. A cabra e Francisco, Carlos Drummond de Andrade 